\title{
Correction to: CRISPR/Cas13a targeting of RNA virus in plants
}

\author{
Kul Bhushan ${ }^{1}$
}

Published online: 25 August 2021

(c) Springer-Verlag GmbH Germany, part of Springer Nature 2021

\section{Correction to: Plant Cell Reports (2018) 37:1707-1712}

https://doi.org/10.1007/s00299-018-2297-2

The corresponding author name contained a mistake in the original publication. The correct name should read as follows: Kul Bhushan.

The original article has been corrected.

Publisher's Note Springer Nature remains neutral with regard to jurisdictional claims in published maps and institutional affiliations.

The original article can be found online at https://doi.org/10.1007/ s00299-018-2297-2.

Kul Bhushan

1sr_bhushan@ rediffmail.com

1 Advanced Centre for Plant Virology, Division of Plant Pathology, ICAR-Indian Agricultural Research Institute, New Delhi 110012, India 